\title{
Effect of Season and Growth Regulators on Flowering, Fruit-Set and Development of the Tomato ${ }^{1}$
}

\author{
M. Pérez-Zapata and G. Ramírez Oliveras ${ }^{2}$
}

\begin{abstract}
Two tomato varieties, Floralou and Marglobe, were treated with spray applications of $\mathrm{N}$-m-tolylphthalamic acid at $0,100,200$, and $300 \mathrm{p} / \mathrm{m}$, and $\mathrm{b}$ naphthoxyacetic acid at $0,15,25$ and $35 \mathrm{p} / \mathrm{m}$ starting at anthesis for six consecutive weeks, totalling six applications. Flowers and quiescent fruits were more abundant during the summer but yield was lower. Growth regulators affected neither flowering nor number of quiescent fruits, but depressed yields. Winter was the best yielding season, although it was the poorest in flowering. B-naphthoxyacetic acid resulted in increased fruit size at the two higher concentrations. Seedless fruits of good quality were produced at the higher concentrations during summer and autumn. Results indicate that flower abscission is not a limiting factor under the conditions of this research.
\end{abstract}

\section{INTRODUCTION}

Theoretically, tomatoes can be planted throughout the year in Puerto Rico, but actually they are planted during the drier months of winter and early spring. There are strong indications that high temperature and high humidity during the summer months (June to September) are unfavorable to tomato production (22). Hemphill and Murneek (7) concluded that the production of greenhouse tomatoes during winter was not as good as production under similar conditions in the spring and early summer. The growth regulator was best utilized when the amount of light was limited.

A major contribution to the understanding of fruit-set was made by Gustafson (5) in 1936, using indolebutyric acid. He showed that in some plants the application of auxins could bring about fruit-set even without pollination.

Since the work of Gustafson, many growth regulators have been used in an attempt to overcome environmental and internal factors involved in flower formation and fruit-set in the tomato.

Moore and Thomas (15) associated the remarkable increase in early yields with either the application of $25 \mathrm{p} / \mathrm{m}$ of $\mathrm{p}$-chlorophenoxyacetic acid or the reduction of light intensity when temperature was above the optimum fruit setting range, or both. Moore (14) also found an increase of $38 \%$ over the control in total yield.

${ }^{1}$ Manuscript submitted to Editorial Board July 9, 1979. Part of a thesis submitted in partial fulfillment of the requirements for the degree of Master of Science, Mayagüez Campus, University of Puerto Rico, Mayagüez, P.R.

${ }^{2}$ Former Assistant Agronomist and Assistant Agronomist, respectively, Agricultural Experiment Station, Mayagüez Campus, University of Puerto Rico, Río Piedras, P.R. 
Howlett (8) proved that indolebutyric acid is very effective in increasing the number and size of tomatoes. The fruits produced with this treatment developed a gelatinous pulp within the locules where seeds were lacking. Unfilled locules resulted in hollow cavities. Further studies (9) proved that this chemical is more effective during low light intensities. Howlett (10) also found premature softening with different growth regulators.

Murneek et al. (18) reported that p-chlorophenoxyacetic acid and bnaphthoxyacetic acid improved fruit-set in greenhouse tomatoes. They obtained increased yields and no malformation using $20 \mathrm{p} / \mathrm{m}$ of bnaphthoxyacetic acid as a whole-plant spray. Further investigation showed that b-naphthoxyacetic acid and p-chlorophenoxyacetic were not effective in increasing yields when light was adequate (17). Moreover, bnaphthoxyacetic acid was better as a whole-plant spray as compared to single cluster spray. Other workers $(6,31,32,33,34,35)$ have found this chemical a promising one to increase fruit-set.

Mullison and Mullison (16) increased yields and fruit size with $75 \mathrm{p} / \mathrm{m}$ of p-chlorophenoxyacetic and $100 \mathrm{p} / \mathrm{m}$ of b-naphthoxyacetic acid. Differential response to the growth regulators among varieties was observed.

Hemphill (6) studied the effect of a-naphthaleneacetic acid, bnaphthoxyacetic acid and p-chlorophenoxyacetic acid at different stages of development of the tomato flowers. Pre-anthesis treatment reduced fruit-set and fruit size, but most fruits were seedless and misshapen. Treatments at anthesis increased fruit-set and fruits were seedless or only partially so. The average fruit size was enlarged by b-naphthoxyacetic acid and p-chlorophenoxyacetic acid, while a-naphthaleneacetic acid reduced it. Sprays applied 4 days after anthesis resulted in the highest yield.

Mann and Minges (12) increased fruit-set with b-naphthoxyacetic acid, p-chlorophenoxyacetic acid, 2,4-dichlorophenoxyacetic and a combination of these chemicals. More than one application of these were injurious to the foliage.

Hemphill (6) increased fruit size with b-naphthoxyacetic acid and pchlorophenoxyacetic acid. Plants sprayed 4 days after anthesis gave the highest yields. Singletary and Warren (23) increased early yield, but not total yield, with whole-plant sprays of p-chlorophenoxyacetic acid and bnaphthoxyacetic acid.

Garcidueñas and Robles (4) reported that sprays at the bud stage and at anthesis induced 20 and $75 \%$, respectively, of the total number of flowers to set fruit, while setting of the control was only $6 \%$. Chapman and Acland (1) could not produce out-of-season tomatoes in Trinidad with applications of b-naphthoxyacetic acid and sucrose.

Wittwer and Teubner (33) increased the number of flowers by spraying the tomato plants at the cotyledon stage with $200 \mathrm{p} / \mathrm{m}$ of $\mathrm{N}$-m-tolylphthalamic acid. They stated that $\mathrm{N}$-m-tolylphthalamic acid is a flower- 
forming, not a fruit-setting chemical. Teubner and Wittwer (25) increased the number of flowers and fruits using $\mathrm{N}$-m-tolylphthalamic acid as a foliage spray on plants treated 9 to 12 days after cotyledon expansion, obtaining the maximum number of flowers in the first cluster. Moore (14) used whole-plant sprays of $\mathrm{N}$-m-tolylphthalamic acid, increasing yields by $80 \%$ over the control; the effect on fruit size, however, was not consistent.

Cordner and Hedger (2) obtained more determinate tomato plants and increased the number of flowers with foliage sprays of $400 \mathrm{p} / \mathrm{m}$ of $\mathrm{N}-\mathrm{m}$ tolylphthalamic acid in single and multiple applications.

Leopold and Scott (11) observed that the failure of flowers to set fruit is usually expressed in two ways: either the flower abscisses or the sepals enlarge and remain attached to the plant with the tiny ovary in a static condition. They found that the underdevelopment of the ovaries was due to an insufficient supply of nutritive materials and not to the lack of growth regulators.

It is unknown whether the effect of season actually reduces the number of flowers or whether it affects pollination, fruit set, or the subsequent development of the fruits. The present study deals with the response of tomatoes to two growth regulating substances when applied to the foliage of two tomato varieties grown during four consecutive seasons. This should give some indication as to the apparent reasons for making one variety more productive than another in the Lajas Valley. It should also indicate whether flowering, fruit-set, or both, have any direct bearing on differentials in production between Marglobe, a poor variety at Lajas, as compared to Floralou, a good variety (21).

\section{MATERIALS AND METHODS}

The gravel culture facilities at the Lajas Substation were used for this study. The unit consists of 14 concrete beds one foot deep, 3.5 feet wide and 50 feet long. Each bed is equipped with an 800-gallon tank and a suction pump.

A factorial experiment in a split-plot design was used. Treatments were replicated three times, with varieties assigned to main plots and growthregulating chemicals to subplots. Each subplot consisted of eight plants spaced 1.5 feet by 2.5 feet. There were 64 plants in each main plot. Six beds were used during each planting season. The beds were sterilized before each planting with a 39\% formaldehyde solution, 1:100.

The two varieties used, Floralou and Marglobe, were direct-seeded and thinned out to leave one plant per hill. Plants were pruned to one stem, staked and sprayed regularly for insect and disease control whenever needed.

During the first week after planting, one pound of ammonium sulfate 
was added to the 800 gallons of water, after which a complete nutrient solution (30) was used for irrigation (table 1). The beds were flushed three times daily and the tanks were maintained at full capacity at all times. The nutrient solution was corrected weekly for available nitrogen, phosphorus, potash, magnesium, calcium and active acidity. The $\mathrm{pH}$ was maintained at 6.5 during the growing period and the whole nutrient solution was replaced three months after planting.

The treatments consisted of N-m-tolylphthalamic acid (NMTA) at 100,200 , and $300 \mathrm{p} / \mathrm{m}$, and beta naphthoxyacetic acid (BNA) at 15, 25, and $35 \mathrm{p} / \mathrm{m}$. Two checks were used, one for each growth regulator, making a total of eight treatments. An aqueous solution of the chemicals

TABLE 1.-Nutrient solution used for the hydroponic tanks ${ }^{1}$

\begin{tabular}{|c|c|c|}
\hline Salt & $\mathrm{p} / \mathrm{m}$ & $\mathrm{Lb}$ of salt $/ 80 \mathrm{gal} \mathrm{H}_{2} \mathrm{O}$ \\
\hline $\mathrm{KNO}_{3}$ & $\begin{array}{l}7145 \mathrm{NO}_{3} \\
4505 \mathrm{~K}\end{array}$ & $7.77 \mathrm{lb}$ \\
\hline $\mathrm{Ca}\left(\mathrm{H}_{2} \mathrm{PO}_{4}\right)_{2}$ & $\begin{array}{l}2721 \mathrm{H}_{2} \mathrm{PO}_{4} \\
562 \mathrm{Ca}\end{array}$ & $2.19 \mathrm{lb}$ \\
\hline $\mathrm{CaSO}_{4}$ & $\begin{array}{l}1596 \mathrm{Ca} \\
3824 \mathrm{SO}_{4}\end{array}$ & $5.40 \mathrm{lb}$ \\
\hline $\mathrm{MgSO}_{4}$ & $\begin{array}{l}1103 \mathrm{Mg} \\
4357 \mathrm{SO}_{4}\end{array}$ & $3.70 \mathrm{lb}$ \\
\hline $\mathrm{Fe}$ (chelated form) & - & $23.0 \mathrm{~g}$ \\
\hline $\mathrm{MnSO}_{4} \cdot 4 \mathrm{H}_{2} \mathrm{O}$ & $\begin{array}{l}2 \mathrm{Mn} \\
3 \mathrm{SO}_{4}\end{array}$ & $2.0 \mathrm{~g}$ \\
\hline $\mathrm{Na}_{2} \mathrm{~B}_{4} \mathrm{O}_{7} \cdot 10 \mathrm{H}_{2} \mathrm{O}$ & $\begin{array}{l}27 \mathrm{Na} \\
93 \mathrm{~B}_{4} \mathrm{O}_{7}\end{array}$ & $69.0 \mathrm{~g}$ \\
\hline $\mathrm{CuSO}_{4} \cdot 5 \mathrm{H}_{2} \mathrm{O}$ & $\begin{array}{l}0.2 \mathrm{Cu} \\
0.2 \mathrm{SO}_{4}\end{array}$ & $0.2 \mathrm{~g}$ \\
\hline $\mathrm{ZnSO}_{4} \cdot 7 \mathrm{H}_{2} \mathrm{O}$ & $\begin{array}{l}0.3 \mathrm{Zn} \\
0.4 \mathrm{SO}_{4}\end{array}$ & $0.40 \mathrm{~g}$ \\
\hline
\end{tabular}

'Following the formula of Withrow and Withrow (30).

was used as a whole-plant spray, using a 1.5-gallon hand sprayer. The first application was made at anthesis of the first flower cluster, followed by a weekly application for a total of 6 weeks. To minimize drift, two plywood boards were used between plots while spraying.

Eight of the most revealing of the 35 attributes studied during the growing and harvesting periods are fully discussed for a clearer over-all picture of this research. Data for eight variants-number of flowers, developed fruits, quiescent fruits, total yield, marketable yield, average weight of marketable fruits, culls, and seedless fruits-were recorded up to the fifth cluster. Quiescent fruits were those undeveloped, unabscissed ovaries (3), which attained some growth but not enough to be classified as a fruit. Fruits were picked mature green and graded into marketable 
fruits and culls (less than $0.1 \mathrm{lb}$ ). Half of the fruits were cut transversally to take seed counts.

Four experiments were planted, one in each planting season, starting May 24; August 24; November 24, 1966; and the last, February 24, 1967. Data for the entire period of the experiments covering temperature, atmospheric humidity, evaporation, rainfall and solar radiation were obtained from the adjacent Weather Bureau Station (table 2).

Statistical analysis of the experimental data as described by Steel and Torrie (24) was made for each experiment, as well as combined analysis to determine the average treatment response over all planting seasons. The Duncan multiple range test to detect differences among treatments was used when the F-test showed significance.

TABLE 2.-Monthly means of climatic factors at Lajas Substation ${ }^{1}$

\begin{tabular}{|c|c|c|c|c|c|c|}
\hline \multirow{2}{*}{ Month } & \multicolumn{2}{|c|}{ Temperature $\mathrm{F}^{\circ}$} & \multirow{2}{*}{ Rainfall } & \multirow{2}{*}{ Evaporation } & \multirow{2}{*}{$\begin{array}{c}\text { Air } \\
\text { Humidity }\end{array}$} & \multirow{2}{*}{$\begin{array}{l}\text { Wind } \\
\text { Movement } \\
\mathrm{M} / \mathrm{h}\end{array}$} \\
\hline & Max. & Min. & & & & \\
\hline & & & In & In & $\%$ & \\
\hline January & 86.00 & 60.80 & 2.17 & 4.97 & 74.53 & 1.57 \\
\hline February & 86.33 & 60.67 & 1.26 & 5.74 & 74.24 & 2.13 \\
\hline March & 87.60 & 61.53 & 1.89 & 7.57 & 69.41 & 2.41 \\
\hline April & 88.13 & 64.40 & 3.60 & 7.62 & 68.31 & 2.58 \\
\hline May & 88.93 & 67.60 & 3.50 & 7.74 & 72.00 & 2.75 \\
\hline June & 90.40 & 68.80 & 2.41 & 7.74 & 60.09 & 2.93 \\
\hline July & 91.00 & 67.93 & 4.08 & 7.99 & 63.3 .13 & 2.60 \\
\hline August & 90.47 & 68.13 & 5.92 & 6.83 & 67.93 & 2.03 \\
\hline September & 89.53 & 68.73 & 6.98 & 5.87 & 70.98 & 1.55 \\
\hline October & 88.13 & 67.47 & 5.38 & 5.44 & 72.27 & 1.32 \\
\hline November & 88.28 & 65.07 & 3.92 & 4.74 & 67.63 & 1.06 \\
\hline December & 86.80 & 62.27 & 2.95 & 4.42 & 81.36 & 1.24 \\
\hline
\end{tabular}

${ }^{1}$ Data covers a span of 15 years for temperature; 20 years for rainfall; 18 years for evaporation; 1 year for air humidity; 12 years for wind movement.

${ }^{2}$ Average of three daily readings (8:00 a.m.; 12:00 noon, and 4:00 p.m.)

\section{RESULTS AND DISCUSSION}

\section{FLOWERING}

The only significant difference among treatments occurred during summer with the application of $200 \mathrm{p} / \mathrm{m}$ of NMTA which resulted in 660 flowers against 543 for the $300 \mathrm{p} / \mathrm{m}$ treatment in the Floralou variety (table 3). The variety $\times$ treatment $\times$ season for the whole year interaction was highly significant. Marglobe produced significantly more flowers than Floralou, 381 vs. 339, in terms of average flowering for the four planting seasons (table 3 ). The interaction variety $\times$ season was highly significant, indicating that the relative superiority of Marglobe varied with season, 
from only $3 \%$ in winter to $17 \%$ in autumn. Overall seasonal averagesseason exclusive of varieties and treatments-shows that the total number of flowers, 512, was greatest in summer. The difference in flowering between summer and each of the other seasons was highly significant. Flowering in autumn, when compared to flowering in each of the other two seasons, spring and winter, differed significantly. Winter and spring flowering did not differ significantly.

The great blooming capacity of Marglobe over Floralou in autumn and spring can be explained only by varietal differences. This same varietal difference accounts for other variants such as developed and quiescent fruits, yield, and average weight of fruits. Flowering was decidedly affected by season, summer resulting in the best flowering followed by autumn. Climatic factors, especially light duration and intensity, and temperature did certainly influence the results.

TABLE 3.-Effect of b-naphthoxyacetic acid (BNA), N-m-tolylphthalamic acid (NMTA) and season on flowering of Floralou $(F)$ and Marglobe $(M)$ tomatoes expressed as average number of flowers per plot

\begin{tabular}{|c|c|c|c|c|c|c|c|c|c|c|}
\hline \multirow{2}{*}{ Treatment } & \multicolumn{2}{|c|}{ Summer } & \multicolumn{2}{|c|}{ Autumn } & \multicolumn{2}{|c|}{ Winter } & \multicolumn{2}{|c|}{ Spring } & \multicolumn{2}{|c|}{ Mean } \\
\hline & $\mathrm{F}$ & M & $\mathrm{F}$ & M & $\mathrm{F}$ & M & $\mathrm{F}$ & M & $\mathrm{F}$ & M \\
\hline Control & 399 & 581 & 296 & 373 & 295 & 300 & 293 & 329 & 321 & 396 \\
\hline $\operatorname{BNA}(15 p / m)$ & 416 & 578 & 301 & 403 & 271 & 291 & 301 & $30) 3$ & 322 & 394 \\
\hline $\mathrm{BNA}(25 \mathrm{p} / \mathrm{m})$ & 399 & 541 & 306 & 367 & 290 & 287 & 198 & 297 & 298 & 373 \\
\hline $\operatorname{BNA}(35, / / m)$ & 422 & 569 & 296 & 332 & 280 & 293 & 293 & 292 & 323 & 371 \\
\hline Control & 457 & 575 & 320 & 379 & 272 & 293 & 294 & 303 & 336 & 388 \\
\hline NMTA $(100 \mathrm{p} / \mathrm{m})$ & 535 & 517 & 310 & 377 & 287 & 299 & 286 & 325 & 355 & 380 \\
\hline NMTA $(200 \mathrm{p} / \mathrm{m})$ & 660 & 553 & 319 & 366 & 298 & 314 & 289 & 317 & 392 & 388 \\
\hline $\operatorname{NMTA}(300 \mathrm{p} / \mathrm{m})$ & 543 & 443 & 340 & 387 & 300 & 281 & 291 & 318 & 368 & 357 \\
\hline Seasonal mean & 479 & 545 & 311 & 373 & 286 & 295 & 281 & 311 & 339 & 381 \\
\hline \multicolumn{11}{|l|}{ Over-all } \\
\hline Seasonal mean & \multicolumn{2}{|c|}{512} & \multicolumn{2}{|c|}{342} & \multicolumn{2}{|c|}{291} & \multicolumn{2}{|c|}{296} & \multicolumn{2}{|c|}{360} \\
\hline
\end{tabular}

\section{DEVELOPED FRUITS}

Independent of varieties, the yearly average of the control, 206 fruits, was superior at the $1 \%$ level to 185 fruits of the $35 \mathrm{p} / \mathrm{m}$ BNA treatment and significantly superior to 191 fruits of the $25 \mathrm{p} / \mathrm{m}$ treatment (table 4). No difference was found between the control and the $15 \mathrm{p} / \mathrm{m}$ treatment. A marked and progressive decrease in developed fruits was observed as BNA concentration increased. No significant difference was found in the NMTA treatments. During the individual plantings, only the summer planting showed a significant decrease in the number of fruits as concentration of both growth regulators increased. The significant interaction treatment $\times$ season shows the effect of both growth regulators on the number of developed fruits. This effect was markedly depressing in 
summer. Floralou, with 213 fruits, was superior at the $1 \%$ level to Marglobe with 181 in total number of developed fruits during the combined four seasons. Although the number of developed fruits in Floralou was always higher than that in Marglobe during the individual seasons, only in winter and spring was fruit development significantly superior.

The relative superiority of Floralou varied from $8 \%$ in autumn to $17 \%$ in spring. The overall season averages (table 4) show that 234 developed fruits in winter were superior at the $1 \%$ level to 166 in summer and 179 in spring, and significantly superior to 211 in autumn. The autumn planting was the second best, being significantly superior to summer and spring. The superiority of Floralou, when compared to Marglobe may be explained by its ability to set fruit under our environment. Winter was the best season in developed fruits for both varieties. Since light is not a

TABLE 4.-Effect of BNA, NMTA and season on developed fruit of Floralou $(F)$ and Marglobe (M) tomatoes expressed as average number of fruits per plot

\begin{tabular}{|c|c|c|c|c|c|c|c|c|c|c|}
\hline \multirow{2}{*}{ Treatment } & \multicolumn{2}{|c|}{ Summer } & \multicolumn{2}{|c|}{ Autumn } & \multicolumn{2}{|c|}{ Winter } & \multicolumn{2}{|c|}{ Spring } & \multicolumn{2}{|c|}{ Mean } \\
\hline & F & M & $\mathrm{F}$ & M & $\mathrm{F}$ & M & F & M & $\mathrm{F}$ & M \\
\hline Control & 196 & 176 & 222 & 211 & 267 & 216 & 208 & $15 \mathrm{I}$ & 223 & 189 \\
\hline BNA $(15 \mathrm{p} / \mathrm{m})$ & 172 & 165 & 215 & 207 & 245 & 222 & 215 & 149 & 212 & 186 \\
\hline BNA $(25 \mathrm{p} / \mathrm{m})$ & 167 & 143 & 226 & 185 & 249 & 204 & 204 & 151 & 212 & 171 \\
\hline $\operatorname{BNA}(35 \mathrm{p} / \mathrm{m})$ & 143 & 141 & 197 & 188 & 245 & 209 & 201 & 149 & 197 & 172 \\
\hline Control & 210 & 185 & 237 & 201 & 252 & 215 & 206 & 152 & 226 & 188 \\
\hline NMTA $(100 \mathrm{p} / \mathrm{m})$ & 193 & 159 & 216 & 217 & 254 & 210 & 202 & 144 & 216 & 183 \\
\hline NMTA $(200 \mathrm{p} / \mathrm{m})$ & 150 & 153 & 229 & 187 & 262 & 232 & 209 & 164 & 212 & 184 \\
\hline NMTA $(300 \mathrm{p} / \mathrm{m})$ & 147 & 149 & 232 & 204 & 254 & 200 & 203 & 152 & 209 & 176 \\
\hline Seasonal mean & 172 & 159 & 222 & 200 & 254 & 214 & 206 & 151 & 213 & 181 \\
\hline Over-all & \multirow{2}{*}{\multicolumn{2}{|c|}{166}} & & & & & & & & \\
\hline Seasonal mean & & & \multicolumn{2}{|c|}{211} & \multicolumn{2}{|c|}{234} & \multicolumn{2}{|c|}{179 . } & \multicolumn{2}{|c|}{197} \\
\hline
\end{tabular}

limiting factor at Lajas, temperature remains the most important one, affecting fruit production. Growth regulators had little effect except in the summer when they depressed the number of fruits. Inconsistent results for both growth regulators reported by different authors $(2,4,6$, $7,12,13,16,17,19,20,23,25,26,27,31,32,33)$ indicate that these chemicals act differently under different conditions. BNA does not increase yields when light is adequate (17), but it does under high temperature and light intensity $(4,16)$.

\section{QUIESCENT FRUITS}

None of the overall responses nor the responses of the growth regulators during individual seasons were significantly different (table 5). Varietal differences for the growth regulators in the yearly averages were highly 
significant in summer but not in the other seasons. The interaction variety $x$ treatment $\times$ season was highly significant. The overall seasonal average (table 5) shows that 164 quiescent fruits in summer were significantly more at the $1 \%$ level than the other three seasons. According to Leopold and Scott (11), quiescent fruits abound after considerable fruit setting has already occurred in the cluster. Our research does not agree with this view, since the lowest number of quiescent fruit, 9, occurred in winter when 234 developed fruits were produced. By the same token, the highest number of quiescent fruits, 164, occurred in summer, when 166 fruits were developed.

Summer, which was the poorest season in developed fruits and total marketable yield, had many quiescent fruits, but it was the best for flowering. Therefore, flower abscission is not a problem at Lajas. Low

TABLE 5.-Effect of BNA, NMTA and season on quiescent fruit of Floralou $(F)$ and Marglobe (M) tomatoes expressed as average of quiescent fruits per plot

\begin{tabular}{|c|c|c|c|c|c|c|c|c|c|c|}
\hline \multirow{2}{*}{ Treatment } & \multicolumn{2}{|c|}{ Summer } & \multicolumn{2}{|c|}{ Autumn } & \multicolumn{2}{|c|}{ Winter } & \multicolumn{2}{|c|}{ Spring } & \multicolumn{2}{|c|}{ Mean } \\
\hline & F & M & F & M & F & $\mathrm{M}$ & $\mathrm{F}$ & M & $\mathrm{F}$ & M \\
\hline Control & 138 & 176 & 44 & 85 & 9 & 11 & 58 & 93 & 62 & 91 \\
\hline BNA $(15 \mathrm{p} / \mathrm{m})$ & 162 & 207 & 47 & 111 & 3 & 12 & 54 & 74 & 67 & 101 \\
\hline BNA $(25 \mathrm{p} / \mathrm{m})$ & 137 & 151 & 49 & 89 & 5 & 17 & 51 & 78 & 60 & 84 \\
\hline BNA $(35 \mathrm{p} / \mathrm{m})$ & 133 & 140 & 50 & 82 & 4 & 11 & 52 & 76 & 60 & 77 \\
\hline Control & 147 & 200 & 58 & 91 & 8 & 14 & 53 & 73 & 66 & 94 \\
\hline NMTA $(100 \mathrm{p} / \mathrm{m})$ & 205 & 144 & 58 & 87 & 7 & 10 & 45 & 87 & 79 & 82 \\
\hline NMTA $(200 \mathrm{p} / \mathrm{m})$ & 258 & 129 & 68 & 94 & 10 & 12 & 50 & 72 & 97 & 77 \\
\hline NMTA $(300 \mathrm{p} / \mathrm{m})$ & 213 & 78 & 57 & 91 & 9 & 8 & 48 & 66 & 82 & 61 \\
\hline $\begin{array}{l}\text { Seasonal mean } \\
\text { Over-all }\end{array}$ & 174 & 153 & 54 & 91 & 7 & 12 & 51 & 77 & 72 & $8: 3$ \\
\hline Seasonal mean & \multicolumn{2}{|c|}{164} & \multicolumn{2}{|c|}{72} & \multicolumn{2}{|c|}{ J } & \multicolumn{2}{|c|}{64} & \multicolumn{2}{|c|}{77} \\
\hline
\end{tabular}

fruit-set during summer is mainly due to a higher percentage of quiescent fruits since there is no heavy flower abscission during this season. The failure of unabscissed flowers to develop into fruits is due more strictly to a limitation of organic nutrients than to deficiency of growth regulators (11). BNA and NMTA effects were not significant for quiescent fruits; thus, this factor is not limiting under the conditions of this research.

\section{TOTAL YIELDS}

A depressing effect of NMTA on yield is indicated by the combined analysis (table 6). The control, with $52 \mathrm{lb}$, was superior at the $1 \%$ level to the $46 \mathrm{lb}$ of the $300 \mathrm{p} / \mathrm{m}$ treatment and significantly superior to the $48 \mathrm{lb}$ of the $200 \mathrm{p} / \mathrm{m}$ treatment. During summer the NMTA control with $45 \mathrm{lb}$ was superior at the $1 \%$ level to $35 \mathrm{lb}$ of the $300 \mathrm{p} / \mathrm{m}$ treatment and 
significantly superior to the $36 \mathrm{lb}$ of the $200 \mathrm{p} / \mathrm{m}$ treatment. No significant difference was found during the other three seasons. Floralou, with $50 \mathrm{lb}$, was significantly superior to Marglobe with $48 \mathrm{lb}$ in the combined analysis, but not in any of the individual seasons. The $64 \mathrm{lb}$ produced in winter was superior to the $39 \mathrm{lb}$ in summer at the $1 \%$ level and significantly higher to production in spring and autumn, with 50 and $43 \mathrm{lb}$ respectively. No difference was found between summer, autumn, and spring. The superiority of Floralou over Marglobe in total yield is due to a higher production of developed fruits, since individual fruit weight was higher in Marglobe than in Floralou. A higher yield was expected in winter when temperatures are moderate and closer to the optimum found by Went $(28,29)$. The depressing effect of the growth regulators may be attributed to the method of application and the concentration. No precaution was

TABLE 6.-Effect of BNA, NMTA and season on total yield of Floralou (F) and Marglobe (M) tomatoes expressed as average pounds per plot

\begin{tabular}{|c|c|c|c|c|c|c|c|c|c|c|}
\hline \multirow{2}{*}{ Treatment } & \multicolumn{2}{|c|}{ Summer } & \multicolumn{2}{|c|}{ Autumn } & \multicolumn{2}{|c|}{ Winter } & \multicolumn{2}{|c|}{ Spring } & \multicolumn{2}{|c|}{ Mean } \\
\hline & $\mathrm{F}$ & M & $\mathrm{F}$ & M & $F$ & M & $\mathrm{F}$ & M & F & M \\
\hline Control & 42 & 39 & 52 & 50 & 65 & 66 & 46 & 41 & $5 \mathrm{I}$ & 49 \\
\hline BNA $(15 \mathrm{p} / \mathrm{m})$ & 42 & 40 & 50 & 55 & 62 & 66 & 48 & 41 & 50 & 50 \\
\hline BNA $(25 \mathrm{p} / \mathrm{m})$ & 44 & 37 & 48 & 47 & 61 & 61 & 49 & 39 & 50 & 46 \\
\hline BNA $(35 \mathrm{p} / \mathrm{m})$ & 36 & 37 & 46 & 51 & 64 & 66 & 48 & 39 & 49 & 48 \\
\hline Control & 49 & 42 & 54 & 50 & 64 & 68 & 49 & 40 & 54 & 50 \\
\hline NMTA $(100 \mathrm{p} / \mathrm{m})$ & 43 & 37 & 49 & 52 & 65 & 65 & 45 & 39 & 51 & 48 \\
\hline NMTA $(200 \mathrm{p} / \mathrm{m})$ & 33 & 39 & 50 & 47 & 64 & 68 & 46 & 40 & 48 & 49 \\
\hline $\operatorname{NMTA}(300 \mathrm{p} / \mathrm{m})$ & 33 & 37 & 48 & 50 & 62 & 60 & 45 & 38 & 47 & 46 \\
\hline $\begin{array}{l}\text { Seasonal mean } \\
\text { Over-all }\end{array}$ & 40 & 38 & 50 & 50 & 63 & 65 & 47 & 40 & 50 & 48 \\
\hline $\begin{array}{l}\text { Sver-all } \\
\text { Seasonal mean }\end{array}$ & \multicolumn{2}{|c|}{39} & \multicolumn{2}{|c|}{50} & \multicolumn{2}{|c|}{64} & \multicolumn{2}{|c|}{43} & \multicolumn{2}{|c|}{49} \\
\hline
\end{tabular}

taken to avoid the harmful practice $(6,17)$ of spraying the very young flower buds.

\section{MARKETABLE YIELD}

In the yearly average $48 \mathrm{lb}$ of the control were superior at the $1 \%$ level to the $43 \mathrm{lb}$ of the $300 \mathrm{p} / \mathrm{m}$ NMTA treatment, and significantly superior to the $44 \mathrm{lb}$ of the $200 \mathrm{p} / \mathrm{m}$ concentration. No significant difference was found between the control and the $100 \mathrm{p} / \mathrm{m}$ treatment. Variety $\times$ treatment interaction was significant during the summer. In the summer the $42 \mathrm{lb}$ of the control were significantly superior, at the $1 \%$ level, to the 30 and $32 \mathrm{lb}$ of the 300 and 200 NMTA p/m concentration, respectively. Neither the growth regulator effects in autumn, spring, and winter nor the $100 \mathrm{p} / \mathrm{m}$ treatment showed significant differences over the control. 
Floralou, with $47 \mathrm{lb}$ was superior to Marglobe with $45 \mathrm{lb}$ at the $5 \%$ level in the yearly average but not in the individual seasons. The winter planting with $64 \mathrm{lb}$ was superior at the $1 \%$ level to each of the other three seasons (table 7). No significant difference was found among the other three seasons. Floralou proved to be better adapted than Marglobe to the conditions under which the experiment was conducted. The winter season was the most adequate for the production of marketable fruit, yielding 30.7 tons/acre with 7,680 plants. The production of profitable yields in other seasons indicates that tomatoes can be planted throughout the entire year. The poorest season, summer, yielded 17.6 tons/acre for Floralou and 16.5 for Marglobe.

\section{WEIGHT OF MARKETABLE FRUITS}

Marglobe, with $0.30 \mathrm{lb}$ was superior at the $1 \%$ level to Floralou with $0.25 \mathrm{lb}$ in the yearly mean weight of fruits as well as in autumn (table 8).

TABLE 7.-Effect of BNA, NMTA and season on marketable yield of Floralou (F) and Marglobe (M) tomatoes expressed as average pounds of marketable fruits per plot

\begin{tabular}{|c|c|c|c|c|c|c|c|c|c|c|}
\hline \multirow{2}{*}{ Treatment } & \multicolumn{2}{|c|}{ Summer } & \multicolumn{2}{|c|}{ Autumn } & \multicolumn{2}{|c|}{ Winter } & \multicolumn{2}{|c|}{ Spring } & \multicolumn{2}{|c|}{ Mean } \\
\hline & $\mathrm{F}$ & M & $\mathrm{F}$ & M & $\mathrm{F}$ & M & $\mathrm{F}$ & M & F & M \\
\hline Control & 38 & 36 & 49 & 46 & 65 & 66 & 44 & 36 & 48 & 45 \\
\hline BNA $(15 \mathrm{p} / \mathrm{m})$ & 50 & 37 & 47 & 51 & 62 & 66 & 45 & 37 & 48 & 47 \\
\hline $\mathrm{BNA}(25 \mathrm{p} / \mathrm{m})$ & 43 & 33 & 45 & 43 & 61 & 61 & 46 & 35 & 48 & 42 \\
\hline BNA $(35 \mathrm{p} / \mathrm{m})$ & 34 & 33 & 44 & 47 & 64 & 66 & 45 & 37 & 47 & 45 \\
\hline Control & 46 & 39 & 51 & 46 & 64 & 68 & 46 & 35 & $5 x$ & 46 \\
\hline NMTA $(100 \mathrm{p} / \mathrm{m})$ & 40 & 34 & 47 & 48 & 65 & 65 & 42 & 35 & 48 & 45 \\
\hline NMTA $(200 \mathrm{p} / \mathrm{m})$ & 29 & 36 & 48 & 43 & 64 & 68 & 42 & 35 & 45 & 44 \\
\hline NMTA $(300 \mathrm{p} / \mathrm{m})$ & 30 & 31 & 45 & 45 & 62 & 60 & 42 & 35 & 44 & 42 \\
\hline Seasonal mean & 37 & 35 & 47 & 46 & 63 & 65 & 44 & 35 & 47 & 45 \\
\hline Over-all & & & & & & & & & & \\
\hline Seasonal mean & \multicolumn{2}{|c|}{36} & \multicolumn{2}{|c|}{47} & \multicolumn{2}{|c|}{64} & \multicolumn{2}{|c|}{40} & \multicolumn{2}{|c|}{46} \\
\hline
\end{tabular}

No significant difference was found between the individual seasons. In the yearly average, $35 \mathrm{p} / \mathrm{m}$ of BNA increased significantly the average weight of marketable fruits from $0.27 \mathrm{lb}$ of the control to $0.29 \mathrm{lb}$, averages of the two varieties (table 8). NMTA failed to promote this increment in weight. Marglobe produced a bigger fruit, a varietal character not affected by season. Fruit size was not affected by season but was improved with $\mathrm{BNA}$, a finding which agrees with previous findings $(6,16)$.

\section{WEIGHT OF CULLS}

Marglobe, with $3.72 \mathrm{lb}$, was significantly inferior to Floralou with 2.82 $\mathrm{lb}$ in total weight of culls (table 9). Marglobe was also significantly a higher producer than Floralou in autumn, but not in the other seasons. 
TABLE 8.-Effect of BNA, NMTA and season on weight of individual marketable fruit of Floralou ( $F$ ) and Marglobe (M) tomatoes, based on average production in pounds per plot

\begin{tabular}{|c|c|c|c|c|c|c|c|c|c|c|}
\hline \multirow{2}{*}{ Treatment } & \multicolumn{2}{|c|}{ Summer } & \multicolumn{2}{|c|}{ Autumn } & \multicolumn{2}{|c|}{ Winter } & \multicolumn{2}{|c|}{ Spring } & \multicolumn{2}{|c|}{ Mean } \\
\hline & $\mathrm{F}$ & M & $\mathrm{F}$ & M & $\mathrm{F}$ & M & $\mathrm{F}$ & M & F & M \\
\hline Control & .25 & .26 & .25 & .26 & .26 & .32 & .26 & .32 & .25 & .29 \\
\hline BNA $(15 \mathrm{p} / \mathrm{m})$ & .26 & .27 & .25 & .29 & .26 & .32 & .26 & .33 & .26 & .30 \\
\hline BNA $(25 \mathrm{p} / \mathrm{m})$ & .27 & .27 & .23 & .27 & .26 & .32 & .27 & .30 & .26 & .29 \\
\hline BNA $(35 \mathrm{p} / \mathrm{m})$ & .27 & .28 & .25 & .30 & .27 & .34 & .27 & .32 & .27 & .31 \\
\hline Control & .24 & .28 & .25 & .28 & .26 & .33 & .27 & .32 & .26 & .30 \\
\hline NMTA $(100 \mathrm{p} / \mathrm{m})$ & .25 & .26 & .25 & .28 & .27 & .33 & .25 & .31 & .26 & .29 \\
\hline NMTA $(200 \mathrm{p} / \mathrm{m})$ & .25 & .28 & .24 & .27 & .26 & .31 & .25 & .30 & .25 & .29 \\
\hline NMTA $(300 \mathrm{p} / \mathrm{m})$ & .24 & .28 & .23 & .28 & .26 & .32 & .26 & .31 & .25 & .29 \\
\hline Seasonal mean & .25 & .27 & .24 & .28 & .26 & .32 & .26 & .31 & .25 & .30 \\
\hline $\begin{array}{l}\text { Over-all } \\
\text { Seasonal mean }\end{array}$ & \multicolumn{2}{|c|}{.26} & \multicolumn{2}{|c|}{.26} & \multicolumn{2}{|c|}{.29} & \multicolumn{2}{|c|}{.29} & \multicolumn{2}{|c|}{.27} \\
\hline
\end{tabular}

TABLE 9.-Effect of BNA, NMTA and season on culls of Floralou (F) and Marglobe (M) tomatoes expressed as pounds per plot

\begin{tabular}{|c|c|c|c|c|c|c|c|c|c|c|}
\hline \multirow{2}{*}{ Treatment } & \multicolumn{2}{|c|}{ Summer } & \multicolumn{2}{|c|}{ Autumn } & \multicolumn{2}{|c|}{ Winter } & \multicolumn{2}{|c|}{ Spring } & \multicolumn{2}{|c|}{ Mean } \\
\hline & $\mathrm{F}$ & M & F & M & F & M & F & M & F & M \\
\hline Control & 4.03 & 3.68 & 2.70 & 3.87 & 2.43 & 2.77 & 2.57 & 4.03 & 2.93 & 3.58 \\
\hline BNA $(15 \mathrm{p} / \mathrm{m})$ & 2.40 & 3.43 & 3.00 & 4.20 & 2.50 & 2.67 & 2.63 & 4.03 & 2.63 & 3.58 \\
\hline BNA $(25 \mathrm{p} / \mathrm{m})$ & 1.63 & 3.57 & 2.90 & 3.63 & 3.23 & 2.07 & 2.10 & 3.70 & 2.47 & 3.24 \\
\hline $\mathrm{BNA}(35 \mathrm{p} / \mathrm{m})$ & 1.83 & 3.70 & 2.37 & 3.90 & 1.97 & 4.03 & 2.47 & 4.10 & 2.16 & 3.93 \\
\hline Control & 2.80 & 4.20 & 2.77 & 3.70 & 1.80 & 2.53 & 2.83 & 4.77 & 2.55 & 3.80 \\
\hline NMTA $(100 \mathrm{p} / \mathrm{m})$ & 3.27 & 3.10 & 2.73 & 3.80 & 3.50 & 2.53 & 2.50 & 3.80 & 3.00 & 3.31 \\
\hline NMTA $(200 \mathrm{p} / \mathrm{m})$ & 4.23 & 3.82 & 2.33 & 3.40 & 3.40 & 4.10 & 3.80 & 4.50 & 3.44 & 3.95 \\
\hline NMTA $(300 \mathrm{p} / \mathrm{m})$ & 3.13 & 5.13 & 3.63 & 4.90 & 3.23 & 2.97 & 3.37 & 4.30 & 3.34 & 4.32 \\
\hline Seasonal mean & 2.92 & 3.83 & 2.80 & 3.92 & 2.76 & 2.96 & 2.78 & 4.15 & 2.82 & 3.72 \\
\hline Seasonal mean & \multicolumn{2}{|c|}{3.71} & \multicolumn{2}{|c|}{3.36} & \multicolumn{2}{|c|}{2.86} & \multicolumn{2}{|c|}{3.47} & \multicolumn{2}{|c|}{3.26} \\
\hline
\end{tabular}

The interaction variety $\times$ treatment was significant in summer and winter. Marglobe produced more culls than Floralou because of heavy loss of fruits with blossom end rot, a condition more pronounced during autumn.

\section{SEED FORMATION}

Both growth regulators stimulated the production of seedless fruit. This effect was highly significant in the overall response and during summer and autumn. There was no significant effect of the growth regulators in winter and spring. Considering the yearly average, the 25 and $35 \mathrm{p} / \mathrm{m}$ of BNA were superior at the $1 \%$ level and the $15 \mathrm{p} / \mathrm{m}$ at the $5 \%$ level as compared to the control. The same effect was noticed during summer and autumn. 
The 200 and $300 \mathrm{p} / \mathrm{m}$ treatments of NMTA were superior at the $1 \%$ level, and the $100 \mathrm{p} / \mathrm{m}$ at the $5 \%$ level, to the control. During summer and autumn the higher concentrations were significantly superior to the lower ones. A significant interaction treatment $\times$ season occurred.

Seed formation was equally affected by the treatments in both varieties. Fruits varied from completely seedless to few seeded for the growth regulator treatments. The summer planting with 21 seedless fruits was superior at the $1 \%$ level to each of the other three seasons. There was no difference between autumn, spring and winter (table 10).

Seedlessness is due to a lack of fertilization, but the fruit is developed because of the stimulating effect of the growth regulators, which supply the effect of pollination and fertilization. Seedless fruits appeared normal, with the cavities filled with gelatinous pulp. During summer and autumn,

TABLE 10.-Effect of BNA, NMTA and season on seed formation of Floralou (F) and Marglobe (M) tomatoes expressed as seedless fruits per plot

\begin{tabular}{|c|c|c|c|c|c|c|c|c|c|c|}
\hline \multirow{2}{*}{ Treatment } & \multicolumn{2}{|c|}{ Summer } & \multicolumn{2}{|c|}{ Autumn } & \multicolumn{2}{|c|}{ Winter } & \multicolumn{2}{|c|}{ Spring } & \multicolumn{2}{|c|}{ Mean } \\
\hline & F & M & $\mathrm{F}$ & M & F & M & F & M & $\mathrm{F}$ & M \\
\hline Control & 10 & 3 & 0 & 2 & 0 & 0 & 0 & 0 & 3 & 1 \\
\hline BNA $(15 \mathrm{p} / \mathrm{m})$ & 16 & 22 & 7 & 7 & 1 & 0 & 2 & 1 & 6 & 8 \\
\hline BNA $(25 \mathrm{p} / \mathrm{m})$ & 13 & 28 & 10 & 10 & 1 & 0 & 2 & 2 & 7 & 10 \\
\hline BNA $(35 \mathrm{p} / \mathrm{m})$ & 23 & 26 & 9 & 11 & 1 & 0 & 1 & 1 & 9 & 10 \\
\hline Control & 4 & 8 & 1 & 1 & 1 & 1 & 2 & 0 & 2 & 2 \\
\hline NMTA $(100 \mathrm{p} / \mathrm{m})$ & 20 & 26 & 6 & 5 & 2 & 1 & 2 & 2 & 7 & 8 \\
\hline NMTA $(200 \mathrm{p} / \mathrm{m})$ & 26 & 42 & 5 & 10 & 2 & 1 & 1 & 0 & 9 & 13 \\
\hline NMTA $(300 \mathrm{p} / \mathrm{m})$ & 26 & 42 & 3 & 9 & 1 & 0 & 2 & 1 & 8 & 13 \\
\hline $\begin{array}{l}\text { Seasonal mean } \\
\text { Over-all }\end{array}$ & 17 & 25 & 5 & 7 & 1 & 0 & 2 & I & 6 & 8 \\
\hline Seasonal mean & \multicolumn{2}{|c|}{21} & \multicolumn{2}{|c|}{6} & \multicolumn{2}{|c|}{1} & \multicolumn{2}{|c|}{1} & \multicolumn{2}{|c|}{7} \\
\hline
\end{tabular}

growth regulators increased the number of seedless fruits. An interaction may be possible between the growth regulators and the higher temperatures in summer and autumn (table 1), especially during the application period from the fifth to the tenth week after planting.

\section{RESUMEN}

Dos variedades de tomate y dos reguladores de crecimiento a tres concentraciones se probaron en cuatro estaciones sucesivamente durante un año, empezando en verano. Las variedades Marglobe y Floralou florecieron profusamente en las cuatro estaciones, pero la más florífera fue la del verano. Los reguladores de crecimiento no afectaron la floración. La abscisión de la flor no parece ser un factor limitativo para la producción del tomate en Lajas. La variedad Floralou fue superior a la variedad Marglobe en rendimiento total. La limitación en la producción 
durante el verano, y hasta cierto punto en primavera y otoño se asocia con el gran número de frutas en estado latente. Según demuestra este estudio la mejor época para la siembra del tomate en Lajas es en los meses de diciembre, enero y febrero, aunque también se consiguieron buenos rendimientos el resto del año.

Los ácidos b-naftaloxiacético (BNA) y N-m-tolilftalámico (NMTA)—los dos reguladores de crecimiento usados en este estudio-disminuyeron el número de frutas en el verano. Con la aplicación de 35 ppm de BNA se logró un incremento del peso individual del tomate comercial. La pudrición apical causó un alto numero de frutas desechables en la variedad Marglobe. Los reguladores de crecimiento BNA a 25 y 35 ppm el NMTA a 200 y 300 ppm indujeron la frutación sin semillas, de buena calidad, en el verano y otoño.

\section{LITERATURE CITED}

1. Chapman, T. and Acland, J. D., 1965. Investigations on out of season tomato production in Trinidad, Trop. Agri. 42-2: 153-62.

2. Cordner, H. B. and Hedger, G., 1959. Determinateness in the tomato in relation to variety and to application of $n$-meta-tolylphthalamic acid in high concentration, Proc. Am. Soc. Hort. Sci. 73: 323-30.

3. Davis, R. M., Smith, P. G., Schweers, V. H., and Scheverman, R. W., 1965. Independence of floral fertility and fruit-set in the tomato, Proc. Am. Soc. Hort. Sci. 86: 552-6.

4. Garcidueñas, M. R. and Robles, J. A., 1965. La caída de la flor en el tomate y su prevención por medio de auxinas, Insti. Tecnol. Est. Sup. Monterrey, México, Bol. 1: $1-18$.

5. Gustafson, F. G., 1936. Inducement of fruit development by growth promoting chemicals, Proc. Nat. Acad. Sci. 22: 628-36.

6. Hemphill, D. D., 1949. The effects of plant growth regulating substances on flower bud development and fruit-set, Univ. Mo. Agri. Exp. Stn. Res. Bull. 434: 1-55.

7. - and Murneek, A. E., 1950. Light and tomato yields, Proc. Am. Soc. Hort. Sci. 55: $346-50$.

8. Howlett, F. S., 1941. Effects of indolebutyric acid upon tomato fruit-set and development, Proc. Am. Soc. Hort. Sci. 39: 217-27.

9. — 1942. Fruit-set and development from pollinated tomato flowers treated with indolebutyric acid. Proc. Am. Soc. Hort. Sci. 41: 277-81.

10. - 1949. Fruit-set and development with particular reference to premature softening following synthetic hormone treatment, Proc. Am. Soc. Hort. Sci. 53: 323-36.

11. Leopold, A. C. and Scott, F. I., 1951. Physiological factors in tomato fruit-set, Am. J. Bot. 39: 310-7.

12. Mann, L. K. and Minges, P. M., 1949. Experiments on setting fruit growth regulating substances un field-grown tomatoes in California, Hilgardia 19: 309-37.

13. Moore, J. F., 1950. Use of p-chloroptenoxyacetic acid spray and two pruning systems to increase yield and fruit size of field-grown tomatoes in western Washington, Proc. Am. Soc. Hort. Sci. 56: 299-302.

14. - 1957. N-1 naphthylphthalamic acid, n-m-tolylphthalamic acid and other growth regulators applied as whole plant sprays on field-grown tomatoes, Proc. Am. Soc. Hort. Sci. 70: 350-5.

15. Moore, E. L. and Thomas, W. O., 1952. Some effects of shading and p-chlorophenoxyacetic acid on fruitfulness of tomatoes, Proc. Am. Soc. Hort. Sci. 60: 289-94. 
16. Mullison, W. R. and Mullison, E., 1948. Effect of several plant-growth regulators on fruit-set, yield and blossom-end rot of six tomato varieties grown under high temperatures, Bot. Gaz. 109: 501-6.

17. Murneek, A. E., 1947. Results of further investigations on the use of "hormone" sprays in tomato culture, Proc. Am. Soc. Hort. Sci. 50: 254-62.

18. - Wittwer, S. H., and Hemphill, D. D., 1944. Supplementary "hormone" sprays for greenhouse-grown tomatoes, Proc. Am. Soc. Hort. Sci. 45: 371-81.

19. Nitsch, F. P., 1962. Basic physiological processes affecting fruit development, Proc. Plant Sci. Symp., Campbell Soup Co., 5-23.

20. Osborne, D. J. and Went, F. W., 1963. Climatic factors. Bot Gaz. 114: 312-22.

21. Rico Ballester, M., López García, J., and Ramos Caro, C., 1968. Evaluación de variedades de hortalizas en las Subestaciones de Fortuna, Lajas e Isabela, Esta. Exp. Agri., Univ. P. R., Publ. Misc. 65.

22. - Influence of season on staked and non-staked tomatoes, (Unpublished data).

23. Singletary, C. C. and Warren, G. F., 1951. Influence of time and method of application of hormones on tomato fruit-set, Proc. Am. Soc. Hort. Sci. 57: 225-30.

24. Steel, R. D. and Torrie, J. H., 1960. Principles and Procedures of Statistics, McGrawHill Book Co., Inc., New York.

25. Teubner, F. G. and Wittwer, S. H., 1957. Effect on n-arylphthalamic acids on tomato flower formation, Proc. Am. Soc. Hort. Sci. 69: 343-51.

26. Van Overbeek, J., 1962. Endogenous regulators of fruit growth, Proc. Plant Sci. Symp., Campbell Soup Co.

27. - 1966. Plant hormones and regulators, Science 151: 721-31.

28. Went, F. W., 1944. Plant growth under contiolled conditions. II. Thermoperiodicity in growth and fruiting of the tomato, Am. j. Hot. 31: 135-50.

29. - and Casper, L., 1945. Plant growth under controlled conditions. VI. Comparisinn between field and air conditioned greenhouse culture of tomatoes, Am. J. Bot. 32: 643-54.

30. Withrow, R. B. and Withrow, A. P., 1948. Nutriculture S. C. 328, Purdue Univ.

31. Wittwer, S. H., 1949. Effect of fruit setting, treatment, variety and solar radiation on yield and fruit size of greenhouse tomatoes, Proc. Am. Soc. Hort. Sci. 53: 349-54.

32. - and Bukovac, M. J., 1962. Exogenous plant growth substances affecting floral initiation and fruit-set, Proc. Plant Sci. Symp. Campbell Soup Co.

33. - and Teubner, F. G., 1956. New practices for increasing the fruit crop of greenhouse tomatoes, Mich. Agri. Exp. Stn. Quart. Bull. 39: 198-207.

34. - Stalworth, H., and Howell, M. J., 1948. The value of a "hormone" spray for overcoming delayed fruit-set and increasing yields of outdoor tomatoes, Proc. Am. Soc. Hort. Sci. 51: 371-80.

35. Zimmerman, P. W. and Hitchcock, A. E., 1944. Substances effective for increasing fruitset and inducing seedless tomatoes, Proc. Am. Soc. Hort. Sci. 45: 353-61. 